\title{
SERUM LIPOPROTEIN PATTERNS IN CORONARY SCLEROSIS AND ASSOCIATED CONDITIONS
}

\author{
BY \\ M. F. OLIVER AND G. S. BOYD \\ From the Department of Cardiology, Royal Infirmary, Edinburgh, and the Department of Biochemistry,
University of Edinburgh
Received November 13,1954
}

The association of coronary sclerosis with a disturbance of lipid metabolism is now fairly generally recognized. The cholesterol of the atherosclerotic plaque is derived, at least in part, from the circulating cholesterol (Biggs et al., 1952). At present the only objective measure of such a disturbance in the living subject is analysis of the circulating lipids. Previously it has been shown that there is significant elevation in subjects of coronary sclerosis compared with the normal of plasma total cholesterol and its ratio to the total circulating phospholipids, the $\mathrm{C} / \mathrm{P}$ ratio (Gertler et al., 1950; Steiner et al., 1952; Oliver and Boyd, 1953b). There is evidence, which has been summarized by Russ et al. (1951), Nikkilä (1953), and Swahn (1953), that the circulating lipids do not exist free in the plasma but are attached to protein. Cholesterol is associated with all the protein fractions but by far the greatest concentration is attached to the $\alpha_{1}$ and $\beta_{1}$ globulin fractions (Blix et al., 1941), thus these two lipid-laden globulin fractions are termed the $\alpha$ and $\beta$ lipoproteins. It is obviously important to study the distribution of cholesterol between these two principal lipid carriers.

An analytical approach towards the estimation of these complex colloidal lipoproteins was only made possible within recent years by the development of new physical methods. The low temperature chemical fractionation of plasma lipoproteins by the elaborate solubility procedure of Cohn et al. (1950), even at the micro level as developed by Russ et al. (1951), requires about $25 \mathrm{ml}$. of serum and considerable technical skill. The ultracentrifugal analytical flotation method, which has been so well developed by Gofman et al. (1950), for the examination of lipoprotein molecules, necessitates the possession of expensive and complex equipment. A third physical characteristic, the different rate of migration of the protein fractions in a buffer in an electric field, may be utilized for the separation of the lipoproteins by zone electrophoresis. This procedure has been applied with various modifications to the study of lipoproteins by Nikkilä (1953), Swahn (1953), and Rosenberg et al. (1954). These authors support the suggestion of Barr et al. (1951), that the normal distribution of cholesterol between the two lipoprotein patterns is changed in the presence of coronary sclerosis and that the concentration of cholesterol on the $\beta$ lipoprotein fraction is increased. The electrophoretic principle is attractive in its simplicity and was therefore employed in this study.

\section{MeThOD}

The subjects were 50 normal healthy men, 50 men with electrocardiographic confirmation of myocardial infarction, two men and two women with xanthoma tuberosum, one man with xanthoma tendinosum, two men with " essential hyperlipæmia" and one boy with progeria. A study of the younger subjects of coronary disease was regarded as particularly important and thus the majority of this group, whose mean age was 41 years, exhibited hypercholesterolæmia, a very frequent finding at this age (Adlersberg, 1951; Oliver and Boyd, 1953b). The control group, which is matched for age, consists of healthy members of university and hospital departments, and in-patients 
who had no history or clinical features of atherosclerosis, cardiac, hepatic, metabolic, or renal disease.

Blood samples were not obtained in the fasting state exclusively. None of the subjects of coronary sclerosis were receiving any therapy at the time of the estimation and none had had a myocardial infarct within three months of the determinations, which were repeated on all 50 subjects on several occasions.

The $\alpha$ and $\beta$ lipoproteins of serum were separated by a filter-paper zone electrophoresis micro technique followed by serial cholesterol estimations. The experimental procedure and method of calculating the $\alpha: \beta$ serum lipoprotein ratio have previously been published (Boyd, 1954). Many serial observations on the same serum sample showed that the accuracy of the $\alpha: \beta$ ratio was \pm 3 per cent. The precise details for the estimation of the plasma total cholesterol and plasma lipid phosphorus have been reported previously (Oliver and Boyd, 1953a).

\section{RESULTS}

The contrast between the serum lipoprotein pattern in the normal with that seen in the presence of coronary sclerosis is shown in Fig. 1, which demonstrates the distribution of cholesterol between the protein fractions. From Table I it can be seen that the percentage of cholesterol attached to the $\beta$ lipoprotein fraction is 72 in the control group in contrast to 91 in the group of comparable age with coronary sclerosis $(\mathrm{P}<0.001)$, and that there is a decrease in the absolute concentration of $\alpha$ lipoprotein in the latter group. The remainder of the cases listed in Table I are an assortment of subjects who exhibit conditions known to be associated with coronary sclerosis. It is interesting that the concentration of cholesterol attached to the $\beta$ lipoprotein fraction in these miscellaneous cases closely resembles the pattern observed in established coronary sclerosis. It seemed justifiable to include in this report these few subjects with conditions known to be associated with coronary sclerosis because they are sufficiently rare to restrict much expansion in numbers.

\section{Discussion}

These results show that the concentration of cholesterol attached to the $\beta$ lipoprotein fraction is increased in a group of men with coronary sclerosis when contrasted with a group of normal men of comparable age, and that the concentration of cholesterol attached to the $\alpha$ lipoprotein fraction is correspondingly decreased. It is important to appreciate that the men with coronary sclerosis studied in this report are all comparatively young and thus the majority exhibited hypercholesterolæmia. The increase in the concentration of cholesterol on the $\beta$ lipoprotein fraction observed in this young group of men with coronary sclerosis was 19 per cent. This compares favourably with an increase of 8 per cent, observed by Barr et al. (1951) using his modification of Cohn's fractionation procedure (Cohn et al., 1950), and with an increase of 9 per cent and 12 per cent in the middle-aged groups studied respectively by Nikkilä (1953) and by Rosenberg et al. (1954) using filter-paper zone electrophoresis. It is probable that the rather greater increase observed in the present study is largely a function of the hypercholesterolæmia which is so striking in young men with coronary sclerosis, and that, whereas the group can fairly be regarded as representative of the young coronary population, it is probably not a cross-section of the coronary population in general. The elevation of plasma total cholesterol and of the plasma $\mathrm{C} / \mathrm{P}$ ratio previously observed in coronary sclerosis (Gertler et al., 1950; Steiner et al., 1952; Oliver and Boyd, 1953b) is to some extent dependent on this increment of cholesterol on the lipoprotein fraction. The $\mathrm{C} / \mathrm{P}$ ratio of the $\beta$ lipoprotein fraction is nearly three times that of the $\alpha$ lipoprotein fraction, and therefore any shift of cholesterol in favour of the $\beta$ lipoprotein fraction will result in elevation of the overall plasma $\mathrm{C} / \mathrm{P}$ ratio.

The behaviour of the serum lipoproteins in diffuse atherosclerosis has not been reported so far and thus it cannot yet be said that the patterns described in coronary sclerosis occur also when atherosclerosis predominantly involves the cerebral circulation or the peripheral circulation. It 

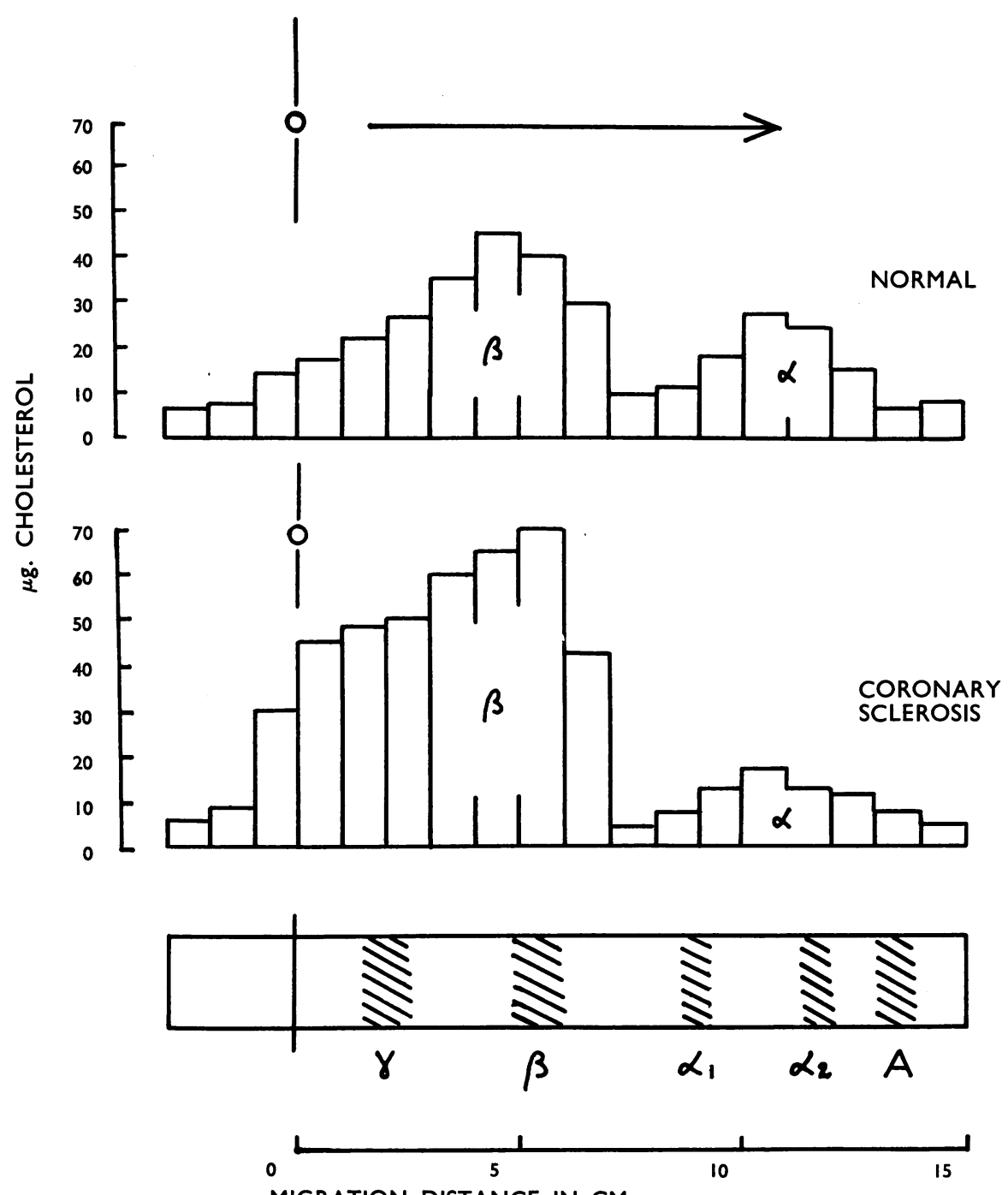

FIG. 1.-The distribution of cholesterol obtained by zone electrophoresis between the $\alpha$ and $\beta$ lipoproteins in normal healthy men and men with established coronary sclerosis. The arrow indicates the direction of migration of the lipoproteins. The lowest diagram illustrates the protein distribution.

TABLE I

Distribution of Cholesterol between the $\alpha$ and $\beta$ Lipoprotein Fractions, expressed as the MEAN $\alpha: \beta$ Ratio, in CORONARY SCLerosis AND SOME AsSOCIATED CONDITIONS

\begin{tabular}{|c|c|c|c|c|c|c|}
\hline Subjects & $\begin{array}{c}\text { Number } \\
\text { of } \\
\text { cases }\end{array}$ & $\begin{array}{l}\text { Mean } \\
\text { age }\end{array}$ & $\begin{array}{l}\text { Mean } \\
\alpha: \beta \\
\text { ratio }\end{array}$ & S.D. & $\begin{array}{c}\text { Mean plasma } \\
\text { total } \\
\text { cholesterol }(\mathrm{mg} \%)\end{array}$ & $\begin{array}{c}\text { Mean } \\
\mathbf{C} / \mathbf{P} \\
\text { ratio }\end{array}$ \\
\hline $\begin{array}{l}\text { Normal men } \\
\text { Men with coronary sclerosis } \\
\text { Xanthoma tuberosum .. } \\
\text { Xanthoma tendinosum ... } \\
\text { "Idiopathic hyperlipæmia } \\
\text { Progeria .. }\end{array}$ & $\begin{array}{r}50 \\
50 \\
4 \\
1 \\
2 \\
1\end{array}$ & $\begin{array}{r}41 \\
41 \\
39 \\
39 \\
37 \\
3\end{array}$ & $\begin{aligned} 28 & : 72 \\
9 & : 91 \\
8 & : 92 \\
4 & : 96 \\
1 & : 99 \\
11: & 89\end{aligned}$ & $\begin{array}{l}9 \cdot 8 \\
6 \cdot 1 \\
= \\
=\end{array}$ & $\begin{array}{l}193 \\
270 \\
371 \\
420 \\
330 \\
235\end{array}$ & $\begin{array}{l}0.82 \\
1.04 \\
0.92 \\
1 \cdot 22 \\
1 \cdot 13 \\
0.99\end{array}$ \\
\hline
\end{tabular}


is thought that these changes are sufficiently striking to warrant a preliminary communication, and that the electrophoretic separation of lipoproteins may become one of the standard procedures in any future attempt at screening the apparently healthy population and a useful adjuvant towards making the diagnosis of coronary sclerosis before it presents clinically. In our experience so far a very high percentage of patients with established coronary sclerosis have had either an elevated plasma total cholesterol or an elevated plasma $\mathrm{C} / \mathrm{P}$ ratio or an abnormal distribution of cholesterol between the serum lipoprotein fractions. On the other hand, some clinically healthy subjects have shown these abnormalities but only time will reveal whether they had incipient coronary sclerosis when the observations were made.

\section{SUMmaRY}

The distribution of cholesterol between the $\alpha$ and $\beta$ lipoproteins has been determined by zone electrophoresis in $\mathbf{5 0}$ men with coronary sclerosis and in $\mathbf{5 0}$ healthy men.

The ratio of cholesterol attached to the $\alpha$ lipoprotein fraction to that attached to the $\beta$ lipoprotein fraction (the $\alpha: \beta$ ratio) has been shown to be significantly lower in the presence of established coronary sclerosis.

We wish to thank Dr. Rae Gilchrist and Professor G. F. Marrian, F.R.S., of our respective departments, for their advice and encouragement, and Mr. Fraser Syme and Mr. William Cooper for technical assistance. We acknowledge gratefully grants from the Secretary of State for Scotland through the Advisory Committee on Medical Research and from the Scottish Hospitals' Endowment Research Trust.

\section{REFERENCES}

Adlersberg, D. (1951). Amer. J. Med., 11, 600.

Barr, D. P., Russ, E. M., and Eder, H. A. (1951). Amer. J. Med., 11, 480.

Blix, G., Tiselius, A., and Svensson, H. (1941). J. biol. Chem., 137, 485.

Biggs, M. W., Kritchevsky, D., Colman, D., Gofman, J. W., Jones, H. B., Lindgren, F. T., Hyde, G., and Lyon, T. P. (1952). Circulation, 6, 359

Boyd, G. S. (1954). Biochem. J., 58, 680

Cohn, E. J., Gurd, F. R. N., Surgenor, D. M., Barnes, B. A., Brown, R. K., Derouaux, G., Gillespie, J. M., Kahnt, F. W., Lever, W. F., Liu, C. H., Mittelman, D., Mouton, R. F., Schmid, K., and Uroma, E. (1950). J. Amer. chem. Soc., 72, 465 .

Gertler, M. M., Garn, S. M., and Lerman, J. (1950). Circulation, 2, 205.

Gofman, J. W., Jones, H. B., Lindgren, F. T., Lyon, T. P., Elliot, H. A., and Strisower, B. (1950). Circulation, $2,161$.

Nikkilä, E. (1953). Scand. J. clin. Lab. Invest., suppl. 8, vol. 5.

Oliver, M. F., and Boyd, G. S. (1953a). Clin. Sci., 12, 217.

-1 - (1953b). Brit. Heart J., 15, 387.

Rosenberg, I. N., Young, E., and Proger, S. (1954). Amer. J. Med., 16, 818.

Russ, E. M., Eder, H. A., and Barr, D. P. (1951). Amer. J. Med., 11, 468.

Steiner, A., Kendall, F. E., and Mathers, J. A. L. (1952). Circulation, 5, 605.

Swahn, B. (1952). Scand. J. clin. Lab. Invest., 4, 98. 